\title{
Development of Friction Force Quiz (F2Q) to Support Learning Evaluation on Friction Force Material in Class X SHS
}

\author{
Edi Supriana ${ }^{1}$, Salsabila Indana Zulfa ${ }^{2}$, Monica Widyaswari ${ }^{3}$, Ulya Aziza Fitriya ${ }^{4}$ \\ \{edi.supriana.fmipa@um.ac.id ${ }^{1}$, salsabilazulfa.1703216@students.um.ac.id ${ }^{2}$, \\ mwidyaswari@gmail.com ${ }^{3}$ \}
}

Department of Physics, Universitas Negeri Malang

\begin{abstract}
Assessment in the education world has a vital role in measuring students' ability to evaluate the subject matter. The application of computer-based assessments is needed because this is following the conditions of technological development in the education world, which is increasingly sophisticated and diverse. Therefore, this article discusses the development of computer-based assessment products on physics material for class X SHS, namely Friction. This product is a computer-based formative assessment implementation system. This product development aims to make it easier to evaluate this material during the current pandemic conditions. This study uses a Research and Development $(\mathrm{RnD})$ research model by applying the Define, Design, Develop, and Disseminate (4D) model. However, this research is only limited to the third stage, Develop. This product, Friction Force Quiz (F2Q), provides evaluation questions equipped with feedback and different levels of difficulty at each level. The level made in this product aims to determine the level of understanding of the student material. Based on product validation and testing results, this F2Q receives a positive and feasible response if used to support the evaluation of learning in the friction force material for class X SHS.
\end{abstract}

Keywords: 4D, Formative Assessment, F2Q.

\section{Introduction}

Physics is a field of science that is generally considered difficult and requires more attention during the learning process. Some of the basic principles of physics are summarized only in simple mathematical form. Apart from understanding concepts through experimentation and analogical processes, learning physics also requires mathematical analysis to find basic principles and predict possible meanings. Although mathematics is not the whole of physics learning, the use of mathematical symbols and the influence of the intuitive language of mathematics in the physics learning process cannot be avoided. Misunderstanding of mathematics and intuitive language will be one of the reasons for the misunderstanding [1],[2].

Friction is an important topic in the study of mechanics [3]. Even though friction is not one of the basic forces, if you understand the concept of friction, the theoretical physics being studied will be more real. In general, many theories in physics are put forward without friction, so they are not suitable for everyday use, such as in free fall, piston motion and 
simple pendulum oscillations. Therefore, with the concept of friction, it is hoped that no one thinks the laws of physics only apply to an ideal world in the laboratory. In addition, it also aims to minimize the view that the knowledge learned in school is abstract and far from real life [4].

The topic of friction in learning physics is an interesting topic to study its level of misconception. This is because there are several different conclusions regarding the high misconceptions in friction force. In the research conducted by Lin and Singh, it was concluded that there are several possible misconceptions that will appear in the friction force material. Most students have the assumption that the static friction force is always a maximum value because students have difficulty with the definition of mathematical inequality related to the magnitude of the static friction against the normal force [2]. This is likely due to the vocabulary of introductory physics and how it is interpreted by students. In addition, this evaluation is needed because currently there are many physics books and online learning sites that discuss friction material inappropriately, especially in static friction. These literatures present the mathematical formulation of static friction in general as the maximum value of the static friction force. The implication of using this formula is feared that it can make students interpret the static friction force to be constant regardless of how much force is exerted on an object [5].

Based on the above it is necessary extra effort is needed to understand physics material, especially friction force material. It is because in this material, almost every year, there are students who do not understand and find it difficult. The difficulty experienced by students lies in determining the direction of the force acting on the object [6]. In addition, having no knowledge about the basic concepts of Newton's law is also one of the reasons students have difficulty working on friction force questions [5], [7]. The friction force is a Physics material that is taught to students since elementary school and is further deepened at the first level of high school [8], [9], [7]. At the elementary school level, this material was introduced for the first time to students in the material style section [10].

This material can be delivered in various ways, including using appropriate learning models, using teaching aids in providing simulations, and also providing enrichment questions to students in order to increase understanding [8], [11], [12], [13]. It is in line with the notion that Physics learning requires learning based on understanding the concept through demonstrations or simulations using teaching aids in a pleasant atmosphere [14]. This pleasant atmosphere can be interpreted by delivering material that is fun using a fun learning model and the evaluation is also not boring [15], [16], [17]. One way to do a fun learning evaluation is by giving evaluation questions that are equipped with animations on the discussion of the problem and also a design that attracts students' interest [8], [18]. In addition, educators can also make project assignments a form of evaluation in learning, [19]. Learning evaluation is an activity to obtain information related to students' understanding of the material that has been received [18].

Currently, there are many technology-based learning evaluations and can be accessed easily by students using gadgets [20]. In this material, many learning media have also been developed to support understanding and are easily accessible. However, the learning evaluation developed on this material is only limited to presenting questions. This model can make students bored and lazy to do it, resulting in poor evaluation results [18]. Therefore, in this study, a Friction Force Quiz (F2Q) is developed. It has a collection of questions to evaluate the friction force material which is equipped with feedback on each answer and there is an animation on the discussion related to problem-solving. 


\section{Method}

Research and Development (R\&D) is the research method used in this research. It is because this research is engaged in product development. The research model used is the $4 \mathrm{D}$ research model. This research model consists of four stages: define, design, develop, and disseminate. Define is the initial stage of a series of stages in the 4D research model, this stage is useful for defining the needs and information needed in this study. At this initial stage, this is a basic step to initiating research, before finally getting the benefits of the results of product development using the 4D research model. While the design stage is the stage that follows up on the results of obtaining initial information or data at the previous stage. The follow-up to this second stage is marked by determining the design that will be used in product development.

Then, the next stage is to develop. This stage is an important step that must be present in the $R \& D$ research model. Because this stage is useful for developing products that have been designed and the reasons and benefits for the design of the product are known. This third stage can also be said to be the most crucial stage of a series of existing stages. It is because at this stage, in addition to the product development process, an initial trial process and input from experts is also carried out regarding the feasibility of this product. So, at a later stage, the product that has been developed only requires a response from consumers when using the product.

The final step of the 4D research model is disseminated. This dissemination step serves to disseminate the results of the design of this product to consumers. The intended users for this product are educators and students because the product produced from this research is a product of learning media. Of the four steps in the 4D research model, only three steps were used in this study: only limited to the third stage, develop. This is due to restrictions on the learning process during the Covid-19 pandemic such as today.

\section{Result and Discussion}

This research produces F2Q products with development stages using the 4D research model. The detailed design of this F2Q product will be presented in the next review. The first review will present the questions or questions that are in the F2Q product. The description of the questions in F2Q is as follows: 


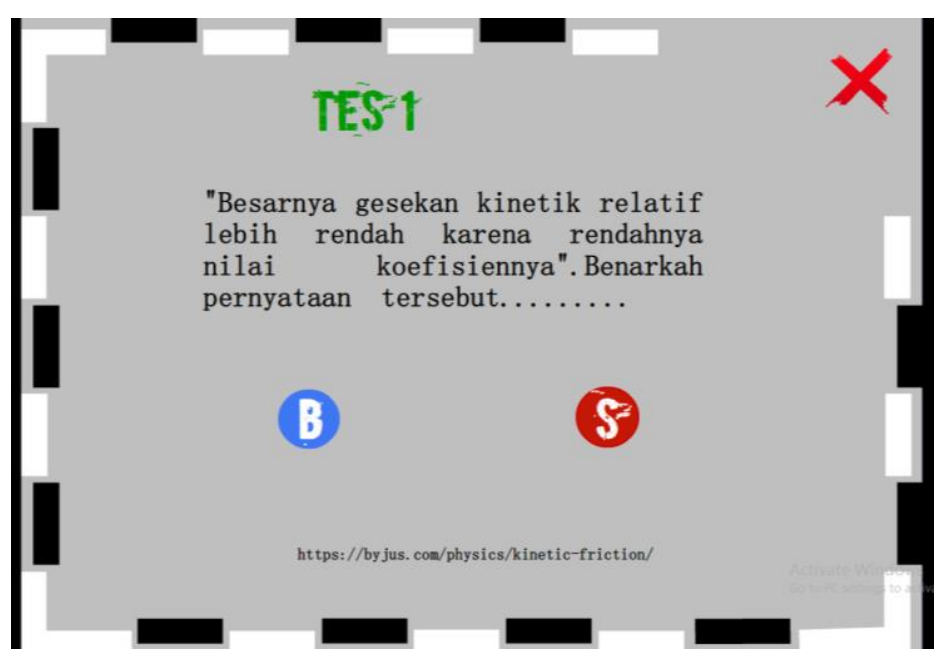

Fig. 1. Question on the first level

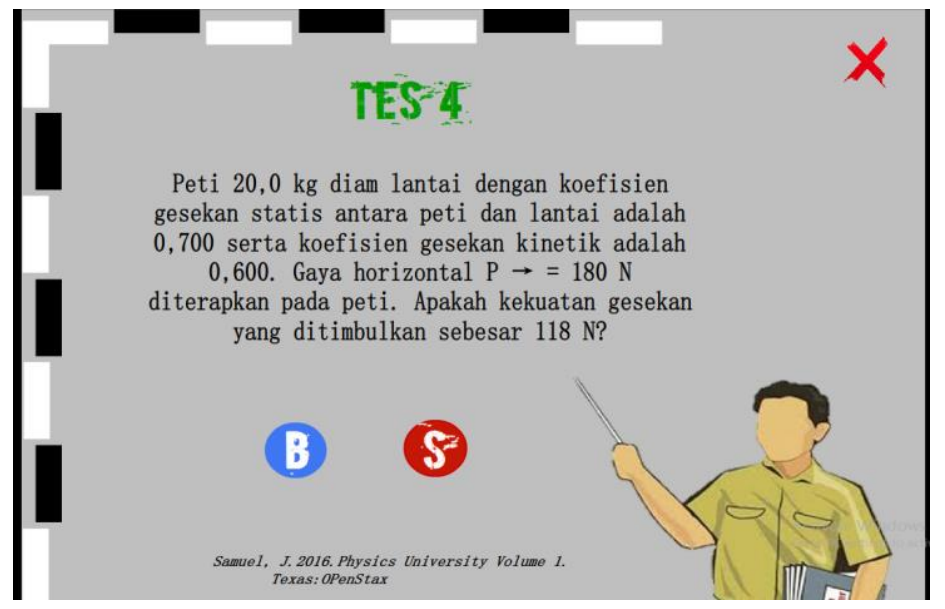

Fig. 2. Question on the second level

At the basic and medium levels, there are types of questions that require an understanding of the concept with a little calculation. The questions at that level use a true and false problem model. So that at this level students are asked to choose whether the existing statement is a true or false statement. 


\section{TES 9}

Koefisien gesekan statis untuk ban mobil balap adalah 0,950 dan koefisien gesekan kinetik adalah 0,800 . mobil berada pada lintasan melingkar setinggi radius $50,0 \mathrm{~m}$

di planet A dimana $g=2,54 \mathrm{~m} / \mathrm{s}$. jika mobil berjalan

tanpa tergelincir pada kecepatan maksimum yang sama di planet ini seperti di bumi, dan jika koefisien

gesekan sama di kedua planet, jari-jari

lintasan di planet A harus sebesar 2 .

\section{(B)

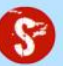

http: //nww. physics. utah. edu/rwoolf/2210_ailion/ex1. p

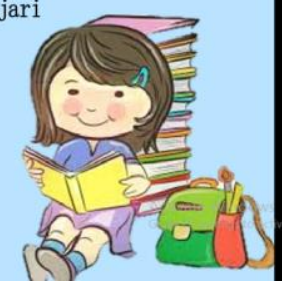

Fig. 3. Question on the third level

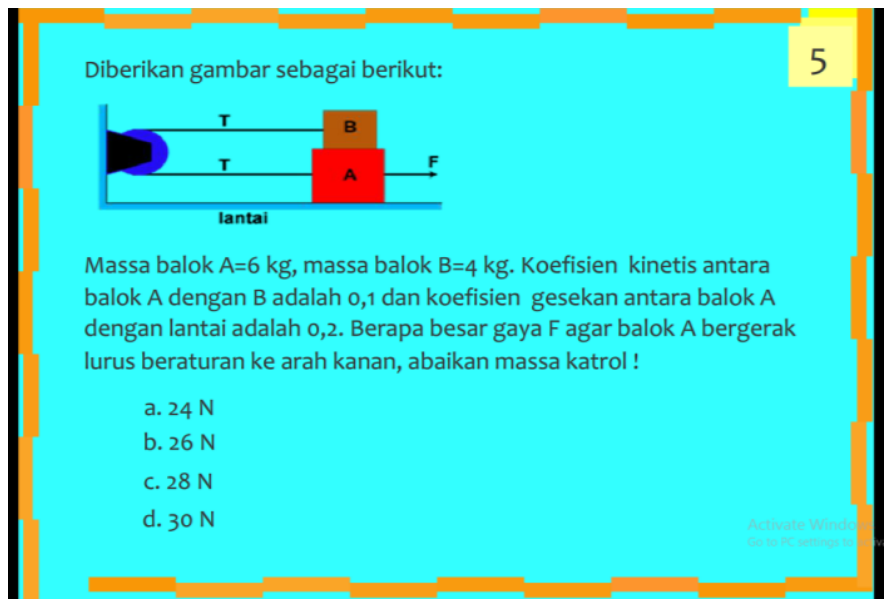

Fig. 4. Question on the third level 


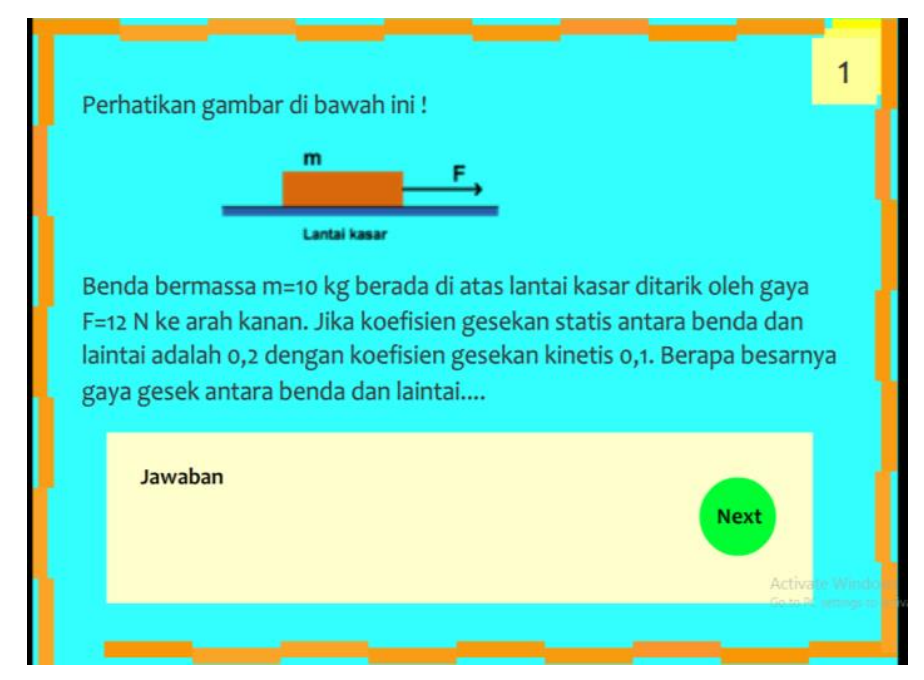

Fig. 5. Question on the third level

are presented at the HOTS question level [21], [22]. Not only that, at this level, there is also an answer analysis using three question models. First, the model of true and false questions is the same as the previous level. Second, a multiple-choice question model with more complex questions, and the third one with a short answer question model that only requires a number answer as the key.

At this design stage, besides determining the model and level of questions and levels of the F2Q product, a flowchart of this product is also designed or what is commonly called a flowchart. The flowchart of the F2Q product is as follows:

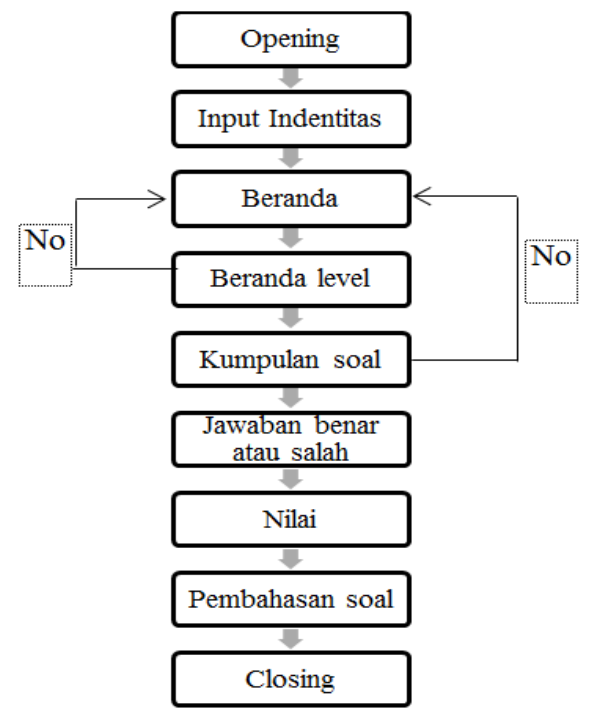

Fig. 6. F2Q product flowchart 
This flowchart explains the flow of the F2Q product. When opening F2Q for the first time, students will be given an attractive initial display to make them curious and want to continue to the next slide. It contains a welcome greeting to the world of physics with friction force sub material kinetic friction material and is equipped with an arrow-shaped button to proceed to the next slide. Not to forget, the developer also provides an atmosphere of relaxation to students by adding a piano instrument back sound which can stimulate the work of the students' brains [23].

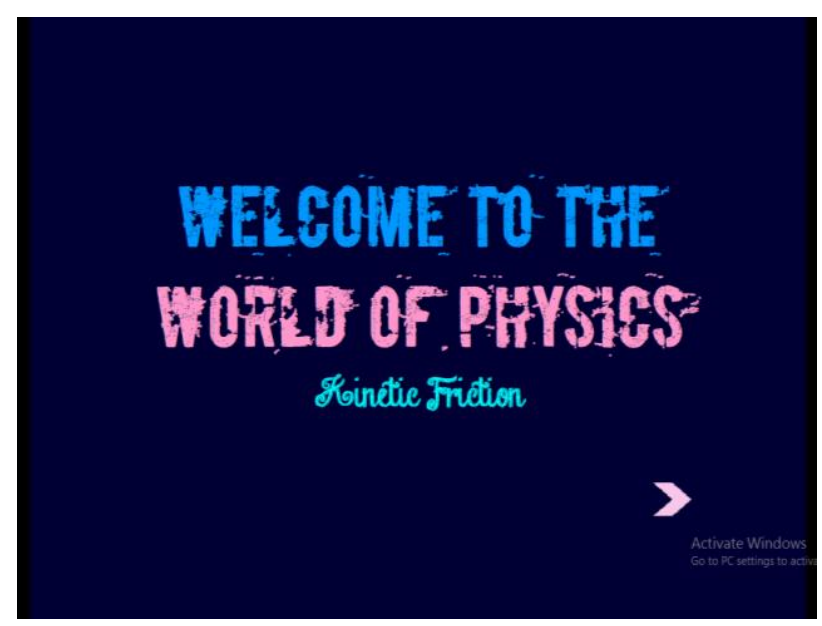

Fig. 7. F2Q opening product preview

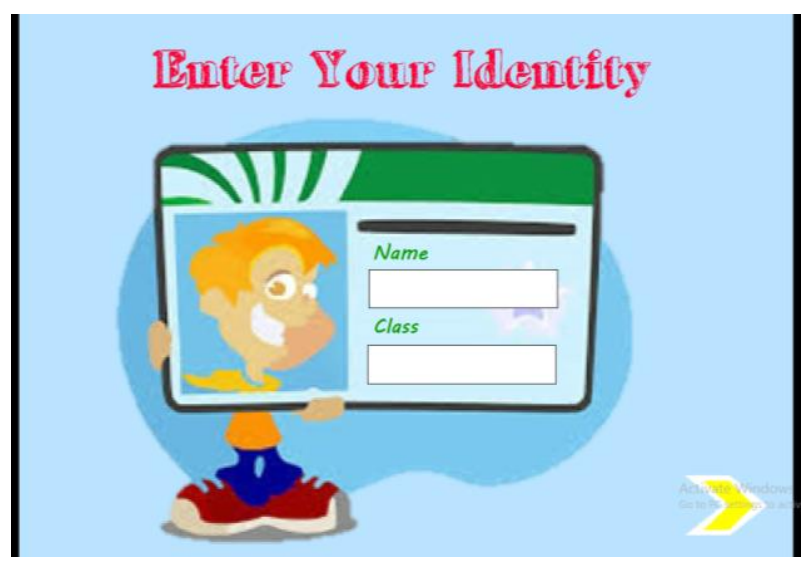

Fig. 8. Input identity in F2Q product

In the next image, the presentation is displayed regarding the identity input display, homepage, and level homepage, where each appearance has a different nuance. This is built to avoid boredom in students when working on questions [24], [25], [26]. In the identity input display, there are two fields that must be filled in, name and class information. Whereas in Figure 9, the F2Q product homepage displays the F2Q product levels. 


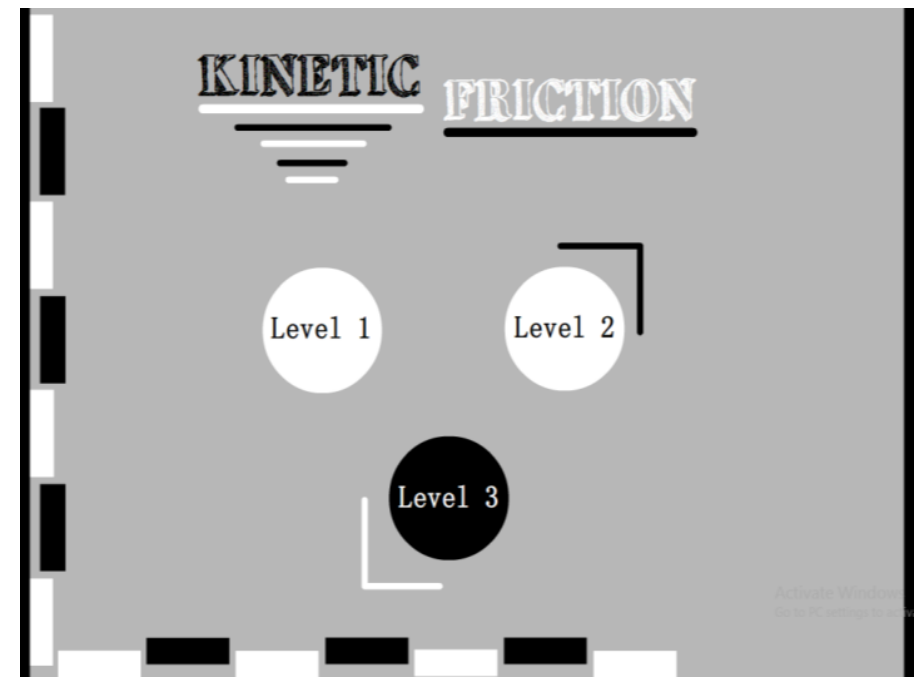

Fig. 9. F2Q homepage preview

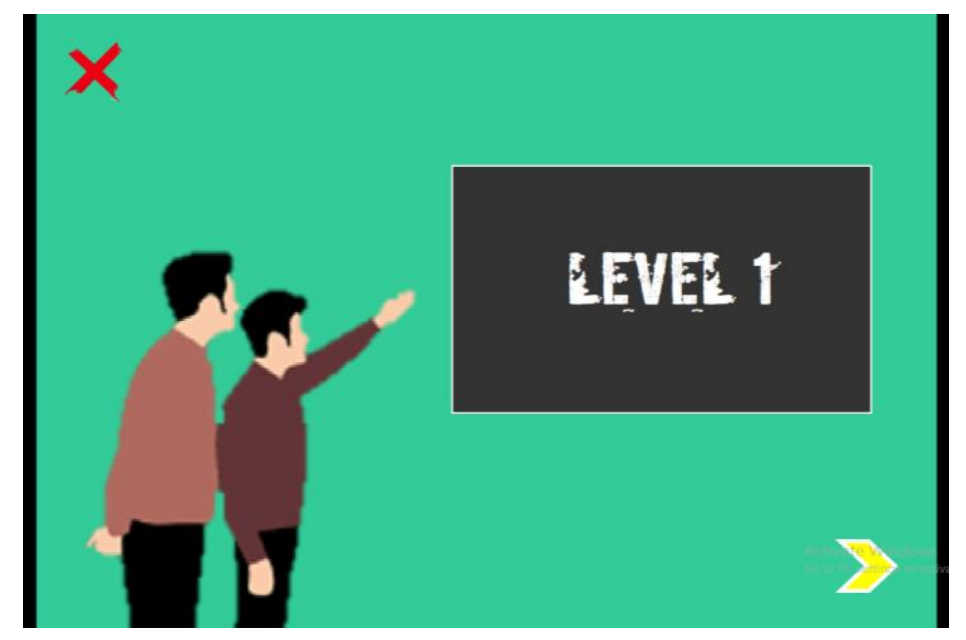

Fig. 10. F2Q level homepage preview

The display in Figure 11 shows the questions available on the F2Q product. These questions come from reputable journal articles and physics books which are then developed to suit the level of students in high school. Then in the next display, there is a response slide available from the student's choice of right or wrong. Whereas in Figure 13 shows the display of the score that was achieved when answering the questions. This score slide, not only displays the score you got, but there is also a button to check the discussion of each question which is equipped with an animation related to the question. Figure 15 shows the last slide of the F2Q product display which contains words of encouragement for students and never gives up. 


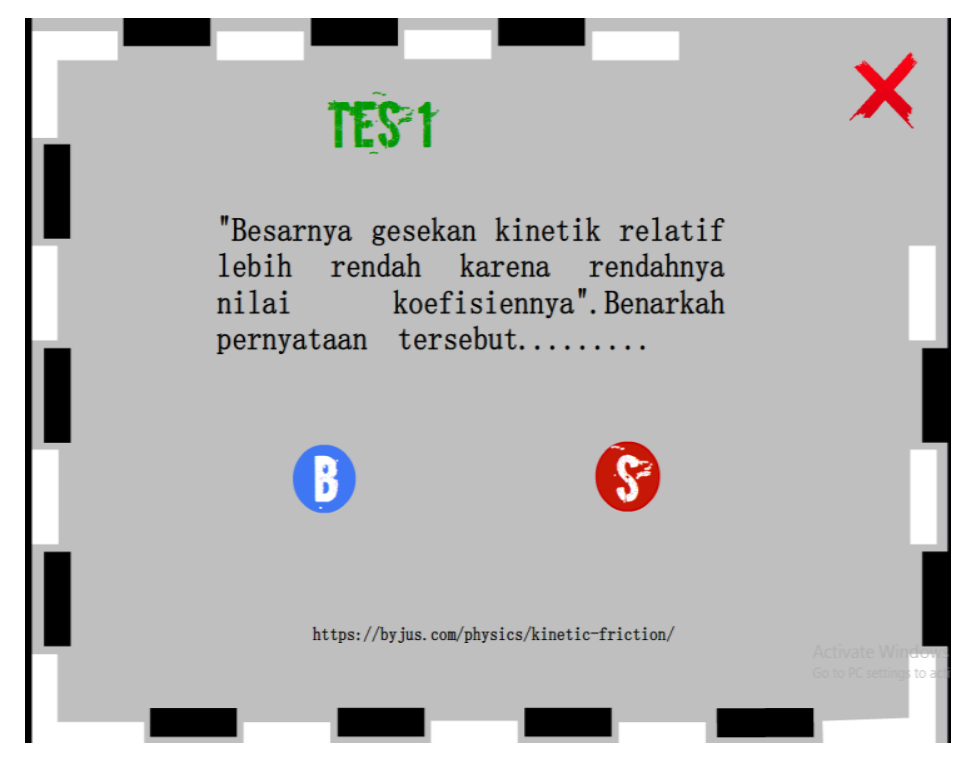

Fig. 11. Question preview on F2Q product

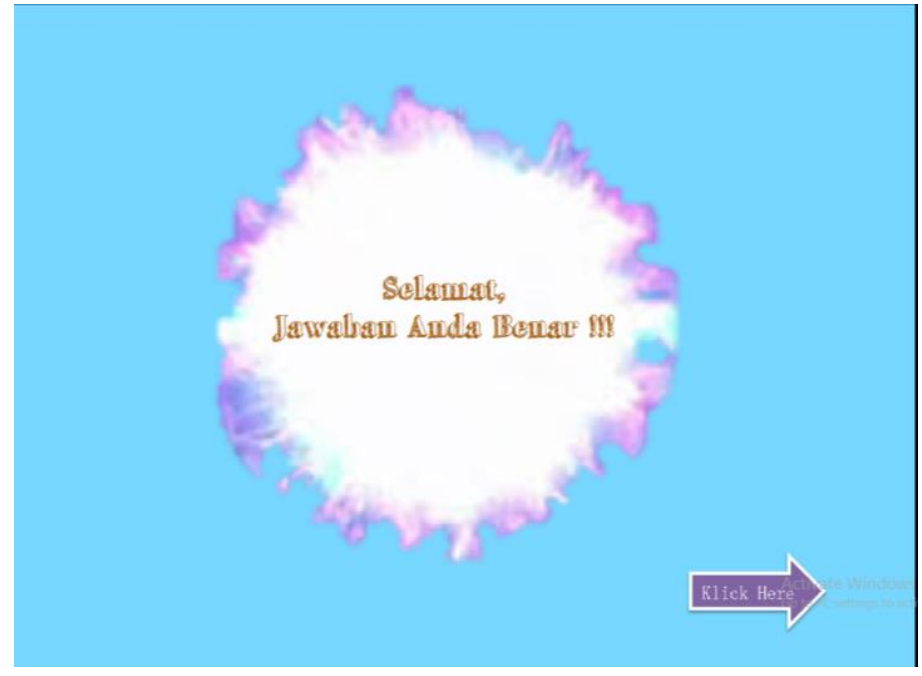

Fig. 12. Answer respon preview on F2Q product 


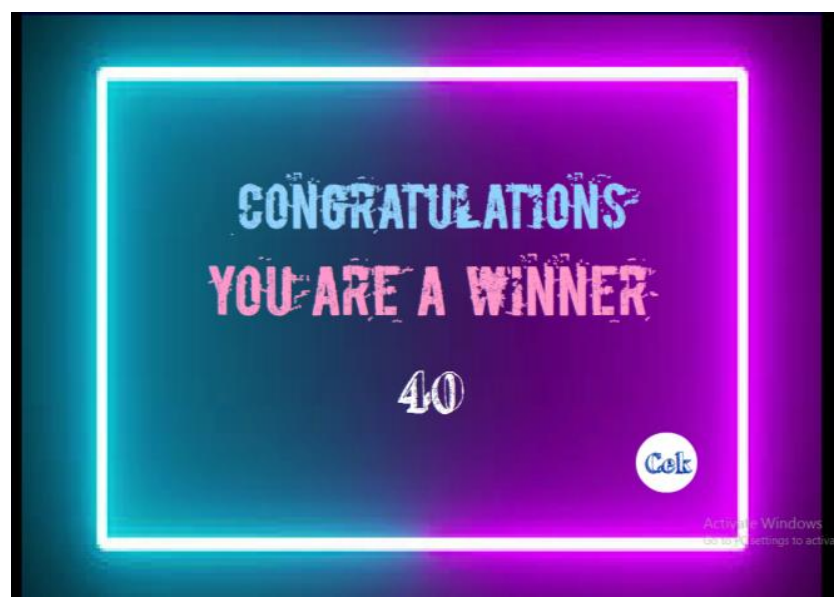

Fig. 13. Score preview

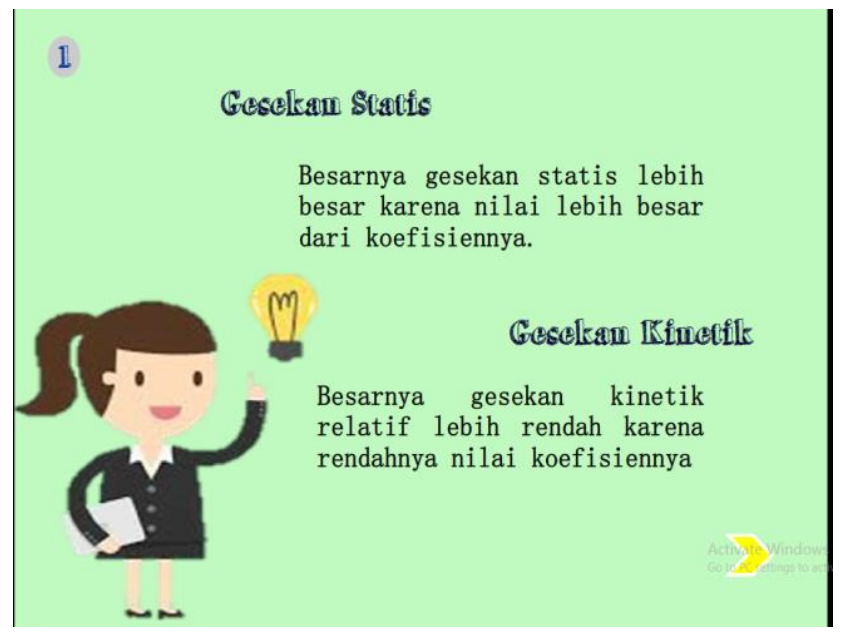

Fig. 14. Discussion of the question preview 


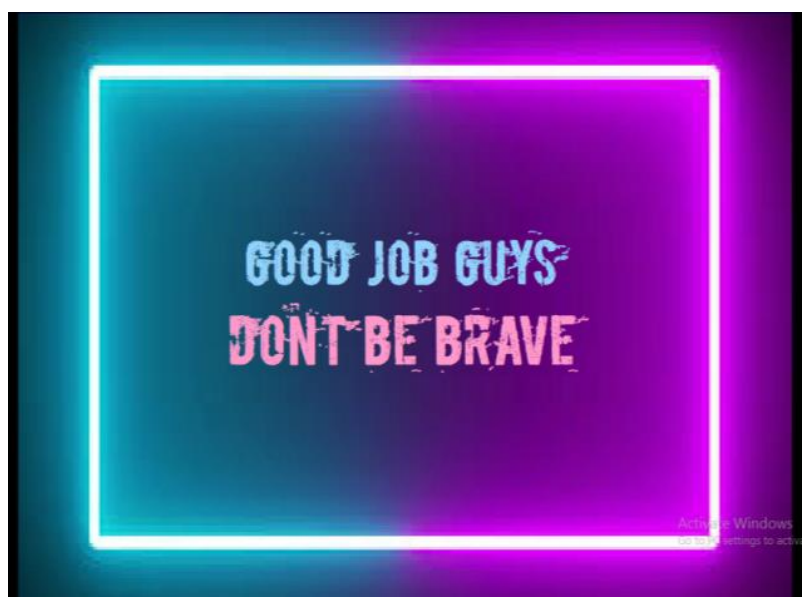

Fig. 15. F2Q product closing preview

After completing the design of the F2Q product. The next stage is to develop the F2Q product. This F2Q product was developed using Macromedia Flash 8 application which can be installed on any Windows software. The choice of an application that is commonly called flash is due to its easy use and relatively comfortable use for novice product developers. At this development stage, input was obtained from experts regarding the mechanism for presenting the discussion of answers and determining levels. Initially, this F2Q product was developed by presenting a discussion of questions after the students chose the answer to the questions. However, according to commentators, the discussion of questions should be put at the end after the score appearance.

In addition, on the homepage display, there is also a change, that initially there was a presentation of material for reviewing the knowledge of students which was eventually eliminated and replaced with a level presentation of the F2Q product levels. Meanwhile, the trial conducted by some undergraduate students of Physics Education at State University of Malang who was currently teaching Computer-Based Assessment courses in 2019 stated that the development of this F2Q product needed to be further developed, so that it could be disseminated more easily.

The research, which begins with the stage of reviewing information from various literature, aims to provide initial information or obtain preliminary data from existing needs in the field. From the results of the literature study, it was found that many students still experienced misconceptions in solving questions. Not only that but students also often find it difficult to do questions, especially questions at the HOTS level. In addition, there are reasons that explain that most students do not understand the basic concept of friction force [27], [28]. The difficulties experienced by students in understanding the basic concepts and solving the friction force problem, among others, are determining the direction of the force and not understanding the concept of Newton's law [6]. Based on the results of the research that had been conducted previously, the data on the test results of students were below the minimum score.

The average score of students' daily tests on friction force material is 38 from the maximum value of 100 [29]. Not only students at the high school level who have problems with friction force material, but university students also often experience difficulties [5]. Based on data obtained from literature study activities, it can be concluded that students need 
a tool to improve their understanding of the friction force material [30], [31]. These tools can be obtained from the development of learning media in the form of a collection of questions that can make students understand more about the material. In addition, you can also use a learning model that can push students to better understand this friction force material, such as the Causal-thinking Approach (CTA), Problem-solving Ability (PSA), and inquiry learning models [11], [32]. In addition, it can also use props to help understand basic concepts during practicum [33], [34].

Based on the data on problems and needs obtained from the defined stage, the next stage, design, is carried out by the product design process. The product design of a collection of questions that are equipped with solving this problem is labeled Friction Force Quiz (F2Q). To find out the increase experienced by students in solving problems, this F2Q product has a different problem difficulty level at each level. This F2Q has three levels: the first level with the problem difficulty level at the basic stage, the second level at the medium stage, and the third level at the question difficulty level at the advanced stage. In this third stage, questions are presented at the HOTS level, while at the previous level it is at the level below HOTS or just basic questions that require conceptual understanding.

Programs developed for kinetic friction material are still rarely found, especially programs that provide enrichment questions such as those in F2Q. Most of the instructional media developers in this material are engaged in making tools, such as practicum tools. Meanwhile, enrichment questions generally come from books or a collection of questions provided by the teacher. Using the HOTS level enrichment questions presented in the F2Q program helps students understand the kinetic friction material.

\section{Conclusions}

This study produces a product that can help support student learning evaluations called F2Q. This Friction Force Quiz is designed not only to help with evaluation activities but also to help provide understanding to students. The F2Q contains a range of enrichment questions from low to high levels. The highest level of questions in the F2Q program is at the HOTS level. Apart from presenting enrichment questions, this program also presents a discussion of questions equipped with interesting animation, this discussion is located at the end of each level. This product is recommended as a complement in delivering the friction force material at the evaluation stage of learning material. Then, this product is only limited to the development, not yet at the dissemination stage. This is because this product is still being developed to make it more perfect so that students can access it in the Playstore. Because at this time, F2Q products can only be disseminated using WhatsApp and Google Drive.

\section{References}

[1] Phanphech, P. Tanitteerapan T, Murphy E. Explaining and enacting for conceptual understanding in secondary school physics. Issues Educ Res. 2019;29(1):180-204.

[2] Master-Khodabakhsh C. An alternative to special relativity: How a flawed experiment and misunderstanding of the fundamental laws of physics diverted physicists from their logical path. Phys Essays. 2020;33(1):79-84. 
[3] Cheng DJ, Park TJ, Kim SJ. Improved friction model for the roller LM guide considering mechanics analysis. J Mech Sci Technol. 2018;32(6):2723-34.

[4] Dewi WS, Afrizon R. Analisis Kondisi Awal Perkuliahan Mahasiswa Pendidikan Fisika Dalam Rangka Mengembangkan Bahan Ajar Statistika Pendidikan Fisika Menggunakan Model Problem Solving. J Eksakta Pendidik. 2018;2(1):93-100.

[5] Tiandho Y. Miskonsepsi gaya gesek pada mahasiswa. J Pendidik Fis dan Keilmuan. 2018;4(1):1.

[6] Januarifin D, Parno P, Hidayat A. Kesalahan siswa SMA dalam memecahkan masalah pada materi Hukum Newton. Momentum Phys Educ J. 2018;2(2):47-55.

[7] Andromeda B, Djudin T, Haratua TMS. Analisis Kemampuan Multirepresentasi Siswa Pada Konsep-Konsep Gaya Di Kelas X Sma Negeri 3 Pontianak. J Pendidik dan Pembelajaran [Internet]. 2017;6(10):1-16. Available from: http://jurnal.untan.ac.id/index.php/jpdpb/article/view/21539/17434

[8] Qosim MY, Handhika J, Sasono M. Pengembangan Media Pembelajaran Koefisien Gesek Kinetik Berbasis Mikrokontroler Atmega Terintegrasi PC Untuk Meningkatkan Keterampilan Proses Sains Siswa. Radiasi J Berk Pendidik Fis. 2020;13(2):40-4.

[9] Riadin A, Fitriani CL. Upaya Meningkatkan Hasil Belajar IPA Menggunakan Model Pembelajaran Kooperatif Tipe JIGSAW dengan Berbantuan Media Alat Peraga Konkret pada Peserta Didik Kelas V SDN-4 Kasongan Baru Tahun Pelajaran 2016/2017. Pedagog J Pendidik. 2018;13(2):1-5.

[10] Gusdianti L, Aeni AN, Jayadinata AK. Pengembangan Keterampilan Proses Sains Siswa Kelas V Pada Materi Gaya Gesek Melalui Pembelajaran Kontekstual. J Pena Ilm. 2017;2(1):651-60.

[11] Rokhmat J, Marzuki, Hikmawati, Verawati NNSP. The causal model in physics learning with a causalitic-Thinking approach to increase the problem-solving ability of pre-service teachers. Pertanika J Soc Sci Humanit. 2017;25(S):153-68.

[12] Humairo S, Astro RB, Amirudin D, Mufida DH, Viridi S. Permukaan Bahan Pada Bidang Miring Menggunakan Aplikasi Analisis Video Tracker. In: Prosiding Seminar Nasional Quantum [Internet]. $2018 . \quad$ p. $132-8 . \quad$ Available from: http://seminar.uad.ac.id/index.php/quantum/article/view/247

[13] Arif MF, Praherdhiono H, Adi EP. Pengembangan Video Pembelajaran IPA Materi Gaya untuk Siswa Sekolah Dasar. J Kaji Teknol Pendidik. 2019;2(4):329-35.

[14] Khoiriah M, Kholiq A. Validitas perangkat pembelajaran fisika berbantuan e-book literasi sains pada materi fluida dinamis. Inov Pendidik Fis. 2020;9(1).

[15] Putra F, Nur Kholifah IY, Subali B, Rusilowati A. 5e-learning cycle strategy: Increasing conceptual understanding and learning motivation. J Ilm Pendidik Fis Al-Biruni. 2018;7(2):171.

[16] Prieto MC, Palma LO, Tobías PJB, León FJM. Student assessment of the use of kahoot in the learning process of science and mathematics. Educ Sci. 2019;9(1).

[17] Asa'd R, Gunn C. Improving problem solving skills in introductory physics using Kahoot! Phys Educ. 2018;53(5).

[18] Purba LSL. Peningkatan Konsentrasi Belajar Mahasiswa Melalui Pemanfaatan Evaluasi Pembelajaran Quizizz Pada Mata Kuliah Kimia Fisika I. J Din Pendidik. 2019;12(1):29.

[19] Santyasa IW, Rapi NK, Sara I. Project Based Learning and Academic Procrastination of Students in Learning Physics. Int J Instr. 2020;13(1):489-508.

[20] Deliana H, Sugianto. Analisis Kebutuhan Pengembangan Design Alat Praktikum Koefisien Gaya Gesek Berbasis Arduino. Pros Semin Nas Pendidik Fis FITK UNSIQ 2020. 2020;2(1).

[21] Ramdiah S, Abidinsyah, Royani M, Husamah. Understanding, planning, and implementation of HOTS by senior high school biology teachers in Banjarmasin-Indonesia. Int $\mathrm{J}$ Instr. 2019;12(1):425-40.

[22] Widana IW, Sumandya IW, Sukendra K, Sudiarsa IW. Analysis of Conceptual Understanding, Digital Literacy, Motivation, Divergent of Thinking, and Creativity on the Teachers Skills in Preparing Hots-based Assessments. J Adv Res Dyn Control Syst. 2020;12(8):459-66.

[23] Andriyanto GK. KONSEP PEMBELAJARAN PIANO: SEBUAH SUMBANGSIH PEMIKIRAN. Tonika; J Penelit dan Pengkaj Seni. 2018;1(1):51-64.

[24] Desyandri D, Muhammadi M, Mansurdin M, Fahmi R. Development of integrated thematic teaching material used discovery learning model in grade $\mathrm{V}$ elementary school. J Konseling dan 
Pendidik. 2019;7(1):16.

[25] Hidayat A, Irawan I. Pengembangan LKS Berbasis RME dengan Pendekatan Problem Solving Untuk Memfasilitasi Kemampuan Pemecahan Masalah Matematis Siswa. J Cendekia. 2017;1(2):51-63.

[26] Batubara HH. Pengembangan Media Pembelajaran Matematika berbasis Android untuk Siswa SD/MI. J Madrasah Ibtidaiyah [Internet]. 2017;3(1). Available from: lib.unnes.ac.id/6871/1/8479.pdf\%0Ahttp://www.albayan.ae

[27] Kurniawan W, Darmaji D, Astalini A, Kurniawan DA, Hidayat M, Kurniawan N, et al. Multimedia Physics Practicum Reflective Material Based on Problem Solving for Science Process Skills. Int J Eval Res Educ. 2019;8(4):590-5.

[28] Cari C, Wulandari PS, Aminah NS, Handhika J, Nugraha DA. Students' understanding level of friction force direction concept on rolling object. J Phys Conf Ser. 2019;1153(1):012150.

[29] Hidayat FS, Handhika J. Profil analisis kebutuhan pengembangan media praktikum gerak melingkar untuk meningkatkan keterampilan proses sains. Semin Nas Quantum. 2018;25(1):10913.

[30] Serway R., Jewett J. Physics for Scientist and Engineers with Modern Physics 9th Edition. 2014. $777-852 \mathrm{p}$.

[31] Knight RD. Physics for Scientists and Engineers_ A Strategic Approach with Modern Physics. Pearson; 2016.

[32] Ceberio M, Almudí JM, Franco Á. Design and Application of Interactive Simulations in ProblemSolving in University-Level Physics Education. J Sci Educ Technol. 2016;25(4):590-609.

[33] Kurniawan W, Handayani DE. Pengembangan Alat Peraga Fisika Pada Materi Gaya Gesek Berbasis Sensor Ultrasonik. J Ilmu Fis dan Pembelajarannya. 2018;2(2):49-52.

[34] Ridho Adi Negoro, Riza Isnaini Ningtyas, Hartono, Supriyadi. Menentukan Nilai Koefisien Gesek Statis Melalui Alat Peraga Gaya Sentripetal untuk Menumbuhkan Sikap Ilmiah Siswa. Risal Fis. 2019;3(2):27-31. 